\title{
Epigenetic Modifications: An Unexplored Facet of Exogenous RNA Application in Plants
}

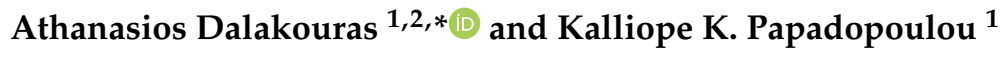 \\ 1 Department of Biochemistry \& Biotechnology, University of Thessaly, 41500 Larissa, Greece; \\ popypapad@gmail.com \\ 2 Institute of Plant Breeding and Genetic Resources ELGO-DEMETER, 57001 Thessaloniki, Greece \\ * Correspondence: nasosdal@gmail.com
}

Received: 5 May 2020; Accepted: 23 May 2020; Published: 26 May 2020

\begin{abstract}
Exogenous RNA interference (exo-RNAi) is a powerful transgene-free tool in modern crop improvement and protection platforms. In exo-RNAi approaches, double-stranded RNAs (dsRNAs) or short-interfering RNAs (siRNAs) are externally applied in plants in order to selectively trigger degradation of target mRNAs. Yet, the applied dsRNAs may also trigger unintended epigenetic alterations and result in epigenetically modified plants, an issue that has not been sufficiently addressed and which merits more careful consideration.
\end{abstract}

Keywords: exogenous RNAi; dsRNAs; siRNAs; PTGS; RdDM; epigenetics

\section{Exo-RNAi and Epigenetic Modifications}

RNAi in plants is triggered by double-stranded (dsRNA) molecules that are cleaved by dicer-like endonucleases (DCLs) into 21-24-nt short interfering RNAs (siRNAs) [1]. More specifically, DCL4 generates 21-nt siRNAs which are loaded on argonaute 1 (AGO1) and slice complementary mRNAs in a process termed post-transcriptional gene silencing (PTGS) [2]. DCL2 produces 22-nt siRNAs which are loaded on AGO1 and either recruit RNA-directed RNA polymerase 6 (RDR6) on the complementary mRNA for the generation of secondary siRNAs [3] or repress mRNA's translation [4]. Lastly, DCL3 processes the long dsRNA into 24-nt siRNAs that are loaded on AGO4 and are involved in RNA-directed DNA methylation (RdDM) of cognate DNA sequences [5].

DNA methylation is an important epigenetic modification and refers to the addition of a methyl group to the fifth carbon of the six-ring cytosine residue. DNA methylation was for long supposed to be induced by DNA:DNA interactions, until a breakthrough study in viroid-infected tobacco plants demonstrated that RNA:DNA interactions trigger DNA methylation, which was thus termed RNA-directed DNA methylation (RdDM) [6]. Although the exact mechanistic details of how RdDM is induced are still elusive, the current model suggests that 24-nt siRNAs dictate which DNA region is to be methylated by hybridizing either with the DNA strand or with its nascent transcript produced by RNA polymerase V (POLV) [7,8]. The interaction of 24-nt siRNA with the POLV transcript recruits, among other factors, the domains-rearranged methyltransferase 2 (DRM2) to de novo methylate the cytosines of the cognate DNA [9]. Although convenient, this model is not completely satisfactory. POLV seems to be recruited at already methylated DNA, thus cannot be involved in the very first step of RdDM on a completely unmethylated locus [10]. Moreover, whole-genome bisulfite sequencing revealed that RdDM is not eliminated in an Arabidopsis quadruple $d c l 1$ dcl2 dcl3 dcl4 mutant, suggesting that siRNAs (24-nt or of any other size class) are not indispensable for RdDM [11]. Indeed, DCL3 and AGO4 are not required for RdDM in inversely repeated loci that readily generate dsRNA [12,13]. It is thus more likely that the very first step of RdDM on a completely unmethylated locus is triggered not by siRNAs but by longer dsRNAs, seemingly with a minimal size of $90 \mathrm{bp}$ [14-16]. The long 
dsRNA may function as a 'ruler' defining the DNA region that will be methylated. Whether one or both RNA strands interacts with one or both DNA strands is open to speculation, but, interestingly enough, long non-coding RNAs (lncRNAs) form triple helices with DNA to regulate gene expression, at least in mammals [17]. According to our hypothesis, the RNA:DNA interaction recruits DRM2 to establish a first (perhaps incomplete) wave of de novo methylation in both DNA strands (Figure 1A). To this hemi-methylated DNA, POLIV and POLV are recruited. POLIV generates short transcripts ( $\sim 40 \mathrm{nt})$ that are transcribed by RDR2 into $\sim 40$-bp dsRNAs [18]. These short POL IV/RDR2 dsRNAs are processed by DCL3 into 24-nt siRNAs that are loaded on AGO4 and hybridize with POLV transcript, recruiting once more DRM2 to the hemi-methylated locus to amplify the methylation marks $[19,20]$ (Figure 1A). Apparently, additional dsRNAs occurring from other sources (e.g., RDR6 transcription of POLII transcripts) may also contribute to this self-reinforcing amplification step [21]. When the de novo and amplification step are finished, all cytosines of the target DNA will be methylated in both strands and in any sequence context: CG, CHG, $\mathrm{CHH}[22,23]$. Importantly, the de novo and amplification steps require the continuous presence of the RNA trigger (dsRNA or siRNA). In the absence of RNA trigger, CG and CHG methylation can be mitotically and meiotically maintained by methyltransferase 1 (MET1) and chromomethylase 3 (CMT3), respectively [24,25]. However, $\mathrm{CHH}$ methylation cannot be maintained in the absence of a RNA trigger [26] (Figure 1A).

Given the tremendous potential of RNAi to silence gene expression in almost all eukaryotes, plant biotechnologists have often resorted to RNAi tools to modify/improve crops and/or protect them against various pests and pathogens. Until recently, this was routinely achieved by transient or stable transformation of plants with transgenes designed to produce dsRNAs against the desired each time target [27-30]. However, the use of genetically modified (GM) crops has failed to gain public and political approval, hence their widespread commercialization has been rendered extremely problematic. Unsurprisingly, plant researchers have lately resorted to induction of RNAi by exogenous application of RNA molecules having the potential to trigger RNAi (exogenous RNAi, exo-RNAi), as an effective and transgene-free alternative to GM crops [31-35]. Indeed, dsRNAs/siRNAs were applied in plants by methods such as spraying, petiole uptake, trunk injection and root absorption in order to modify plant gene expression [36-39] and to confer resistance against viruses [40-44], fungi [45-49] and insects [50-54]. In the near future, one may envisage that exo-RNAi could potentially replace conventional herbicides, fungicides and insecticides, and a great amount of effort is invested in this direction by most major crop industries [55]. Of course, minimization of dsRNA production costs and optimization of dsRNA stability and uptake by the target organism is a sine qua non for field scale applications. To this end, several agroindustrial companies (e.g., RNAgri, agroRNA, GreenLight Biosciences) offer large amounts of dsRNA for as low as one US dollar per gram dsRNA, while various carrier compounds (e.g., clay nanosheets, chitosan nanoparticles, liposomes) were developed that significantly improve dsRNA's stability against the environmental nucleases and uptake from the target organism. Accordingly, an exo-RNAi commercial product ('BioDirect' from Monsanto/Bayer) designed for insect, weed and virus control is very close to reach the market [55].

Already from the early days of RNAi discovery in plants, it has been well established that PTGS is tightly connected to RdDM [56]. It has thus been surprising that, despite the huge progress and the rapidly accumulating reports on exo-RNAi applications, the question as to whether the applied dsRNA induces not only mRNA degradation, but also DNA methylation, has skipped the attention of the researchers, with a notable exception. When Dubrovina and co-workers applied in vitro transcribed GFP and NPTII dsRNA in transgenic Arabidopsis carrying a GFP/NPTII cassette, they observed seven days post application not only GFP and NPTII mRNA downregulation, but also DNA methylation of the corresponding coding regions [38]. Arguably, transgenes are more prone to transitivity, systemic silencing and RdDM than endogenes are [57,58]. Nevertheless, native endogenes are certainly not immune to RdDM, since they can also be targeted for methylation, e.g., upon the presence of RNA viruses (exogenous RNAs themselves) that replicate through dsRNA intermediates $[59,60]$. Hence, the data from Dubrovina and co-workers seem to reflect a more generalized mechanism and 
underpin that the issue of possible epigenetic changes in exo-RNAi applications merits more careful consideration, since the plants treated with exogenous RNA may still be GM-free, but epigenetically modified, nevertheless.
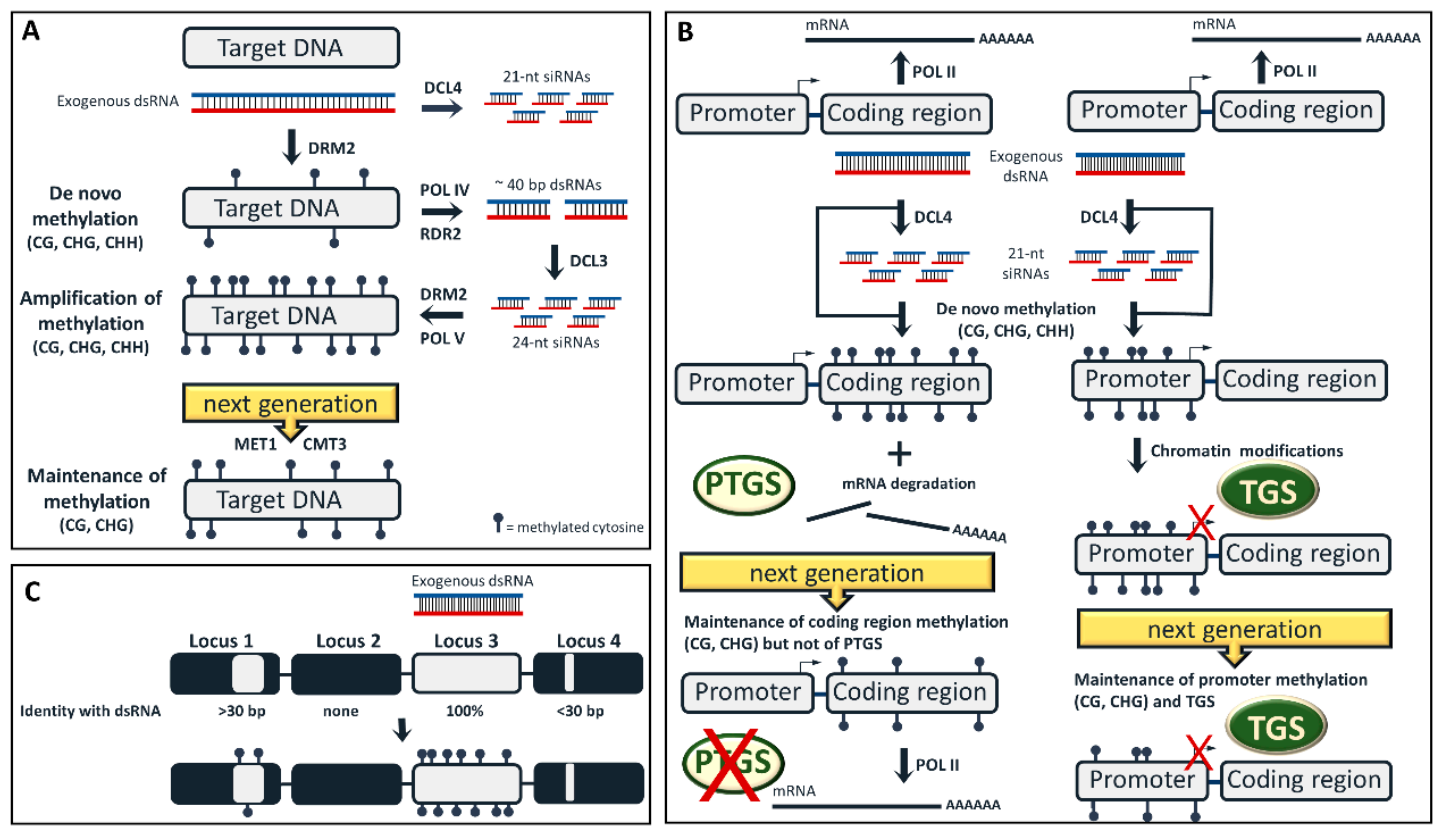

Figure 1. Epigenetic modifications upon exogenous RNA interference (exo-RNAi) application. (A) The three steps of DNA methylation: de novo, amplification and maintenance. Exogenously applied double-stranded RNAs (dsRNAs) are mainly processed by dicer-like 4 (DCL4) into 21-nt short-interfering RNAs (siRNAs) that have no direct role in RNA-directed DNA methylation (RdDM) in the nucleus, but they mediate post-transcriptional gene silencing (PTGS) in the cytoplasm. According to our hypothesis, the exogenous long dsRNA triggers the first incomplete wave of de novo methylation, while the 24-nt siRNAs, that are subsequently generated upon RNA polymerase IV (POLIV) transcription of the de novo methylated locus, are seemingly involved in the amplification of these methylation marks. Thus, both long dsRNAs and 24-nt siRNAs are able to recruit domains rearranged methyltransferase 2 (DRM2) to their target in a stepwise manner. In the absence of RdDM trigger molecules (dsRNA or siRNAs) $\mathrm{CHH}$ methylation is mitotically/meiotically lost, while CG and CHG methylation are maintained by methyltransferase 1 (MET1) and chromomethylase 3 (CMT3), respectively. (B) Exogenous application of dsRNA designed to target a coding region (left) will result not only to mRNA degradation aPTGS, but also to RdDM of the coding region. In the next generation, PTGS will be lost, but DNA methylation (CG and to lesser extent $\mathrm{CHG}$ ) will be maintained. Exogenous application of dsRNA designed to target a promoter (right) will lead to promoter RdDM. Should additional chromatin modifications occur, TGS will also take place. In the next generation, $\mathrm{CHH}$ methylation will be lost, but $\mathrm{CG} / \mathrm{CHG}$ methylation and TGS will be maintained. (C) A dsRNA may trigger RdDM not only to a DNA sequence which shares full sequence identity (locus 3, on-target), but also to an unrelated DNA sequence exhibiting a minimum of 30-bp sequence identity with the dsRNA (locus 1, off-target).

Plant DCLs colocalize in the nucleus [61]. Yet, PTGS takes place in the cytoplasm [62]. Thus, during exo-RNAi, the applied dsRNA would need to first reach the nucleus and be processed by DCLs into siRNAs that would subsequently trigger PTGS in the cytoplasm. Of note, in exo-RNAi approaches that involve application of siRNAs (and not dsRNAs), transportation of siRNAs in the nucleus would not be required. Exogenous application of dsRNA in plants has been repeatedly reported to trigger PTGS of plant-encoded mRNAs [38,63-66]. This highlights that the exogenously applied dsRNA indeed manages to reach the nucleus, perhaps with the aid of dsRNA-binding proteins, where it is processed by DCLs into siRNAs. Importantly, while being in the nucleus, the exogenous dsRNA may also trigger RdDM of the cognate DNA sequences (Figure 1A). Thus, the researchers should take into consideration 
that when they apply dsRNA in plants to target a given mRNA for PTGS, they unintentionally also trigger RdDM of the corresponding coding region in CG, CHG and CHH context (Figure 1B). It is not clear how gene body CHG and CHH methylation affect transcription, but at least CG methylation does not seem to impede it $[67,68]$. Thus, in the dsRNA-treated plants, the transcript from the methylated gene body will continue to be produced, but once it reaches the cytoplasm, it will be targeted by the occurring siRNAs for degradation and PTGS (Figure 1B). It should be noted here that plants gametes are formed from somatic cells. However, even if the somatic cells from which the gametes originated were dsRNA-treated, PTGS will not be maintained in the dsRNA-free progeny and neither will CHH methylation. Yet, CG and, to lesser extent, CHG methylation will be trans-generationally inherited [68] (Figure 1B). That being said, both dsRNA-treated plants and their dsRNA-free progeny will be epigenetically modified.

Interestingly, while both intron-containing genes and intronless genes are in principle susceptible to coding region methylation, intronless genes are much more so, presumably because their transcripts are much more prone to RDR6 processing into secondary dsRNAs and siRNAs that amplify both PTGS and RdDM. Indeed, both intron-containing and intronless genes may generate, besides the legitimate mRNAs, aberrant RNAs (abRNAs) as well, that is transcripts devoid of 5' cap and/or 3' polyadenylation tail. These potentially deleterious abRNAs need to be quickly eliminated by the plant cell. Thus, abRNAs from intron-containing genes are exonucleolytically degraded, due to their prior association with the spliceosome, whereas abRNAs from intronless genes are channeled to the RDR6/DCLs pathway for endonucleolytic degradation [57,58]. Of note, the transcription rate of each gene seems to be positively correlated with the likelihood for abRNA generation. Based on what was discussed above, when the exo-RNAi target is a moderately expressing intron-containing gene, then exogenous RNA application will result in local but most probably not in systemic silencing, while the risk of concomitant epigenetic modifications in the corresponding coding region will be low. In contrast, when the exo-RNAi target is a highly transcribed intronless gene, the chances to achieve both local and systemic silencing upon exogenous RNA application are high, as is also the risk of concomitant epigenetic modifications in the coding region. Conceivably, exceptions to this general rule of thumb are very likely to exist.

While DNA methylation of coding regions does not seem to affect transcription, DNA methylation of promoter regions has a very different effect. Methylated cytosines in the promoters are recognized by methyl-binding proteins (MBDs) that recruit histone methyltransferases (SUVHs) and histone deacetylases (HDACs) [69-71]. Histone methylation and deacetylation increase histone positive charge and thus the negatively charged DNA wraps around them more tightly in the nucleosome. As an outcome, the occurring condensed chromatin blocks POLII access and results in transcriptional gene silencing (TGS) [72-75]. It has not been tested so far whether exogenous RNAs designed to target promoter sequences can efficiently lead to TGS which, in contrast to PTGS, could be trans-generationally maintained [76] (Figure 1B). This could indeed be a challenging task, since promoter RdDM does not always lead to chromatin modifications and TGS. More specifically, while both transgenic and endogenous promoters are prone to $\mathrm{RdDM}$, endogenous promoters are less prone to subsequent chromatin modifications and TGS for reasons that are not clear [77]. Interestingly, the few endogenous promoters that are prone to TGS derive from tissue-specifically expressed genes [28].

It needs to be noted here that the risk of epigenetic modifications upon exo-RNAi refers primarily to cases when the target is a plant gene. When the target is an RNA virus, then exo-RNAi will lead only to PTGS and not to RdDM, since there is no cognate DNA coding region in the virus (DNA viruses being an exception). Similarly, when the target is an insect or a fungal mRNA, then the exogenously applied dsRNA needs to function inside the insect and fungal cell, respectively, where RdDM has not been reported to occur. However, an exogenous dsRNA originally designed to function inside the insect or fungal cell, may also exhibit biological activity in the plant cell, given the opportunity. Conceivably, an exogenous dsRNA applied against insect/fungal targets will most certainly not exhibit full sequence identity to a plant target, but it may exhibit partial sequence identity with a plant locus, 
nevertheless. Importantly, a sequence identity as small as $30 \mathrm{bp}$ between a given dsRNA and the plant DNA is enough to trigger RdDM of the plant DNA [23] (Figure 1C). Not to mention that if this 30-bp sequence identity happens to cover a plant coding region, then the 21-nt siRNAs that will be generated from the 30-bp dsRNA region will target the plant mRNA for degradation and PTGS. However, in that case, it is doubtful that the occurred cleaved transcripts will be processed by RDR6 into secondary dsRNAs and secondary siRNAs that will further amplify the silencing events in a ricochet-like manner [78]. Generation of secondary siRNAs and phased siRNAs (phasiRNAs) takes place only in few cases and only when the transcript is recognized by 21-22-nt miRNAs having an asymmetric bulge and/or by 22 -nt siRNAs $[3,79,80]$. It was recently suggested that exogenously applied dsRNA are mainly processed to 21-nt siRNAs (and not to 22-nt siRNAs) and as such are unlikely to trigger transitivity [81]. Of note, exogenously applied 22-nt siRNAs, which are the most potent inducers of systemic silencing [37], will most certainly trigger transitive PTGS and transitive RdDM, especially in highly transcribed intronless genes.

Last, but not least, the mode of RNA application in plants greatly influences the onset of RNAi and the risk for epigenetic off-target effects. Thus, while high-pressure sprayed RNAs and/or low-pressure sprayed formulated RNAs are efficiently delivered inside the plant cells, trunk injected and petiole absorbed RNAs are transported through the apoplast and the xylem and thus do not exhibit any biologic activity in the plant cell $[36,37]$. Whereas symplastic RNA delivery is desired when the RNAi target is a plant gene or a virus located in the plant cell, the apoplastic RNA delivery is best suited in circumstances when the RNAi target is an insect or a fungus, since the latter need to uptake intact dsRNA (unprocessed by plant DCLs) in order to process it themselves to siRNAs with optimal biochemical RNAi properties [31]. Nevertheless, it is highly advisable that all exo-RNAi approaches, even those where the target is non-plant, are carefully designed to select non-conserved regions as targets so as to avoid undesired epigenetic off-target effects. To this end, applying unique chemically synthesized siRNAs, rather than longer dsRNAs (which are processed by DCLs into a plethora of diverse siRNA population) may also reduce off-target effects.

Overall, we strongly propose here that the occurrence of epigenetic changes in the genome upon exo-RNAi applications should be addressed and clarified in future studies. This will not only help to better interpret the obtained exo-RNAi data, but also to more comprehensively shape the regulatory framework of this exciting new technology. Although the European Food Safety Authority (EFSA) and other international risk assessment bodies and regulatory agencies have already addressed the issue of GM-based RNAi plants, there are still no clear guidelines for exo-RNAi applications $[55,82]$.

Author Contributions: Conceptualization, A.D.; writing—original draft preparation, A.D.; writing-review and editing, A.D. and K.K.P.; funding acquisition, A.D., and K.K.P. All authors have read and agreed to the published version of the manuscript.

Funding: This research was funded by European Union's Horizon 2020 research and innovation program under the Marie Skłodowska-Curie grant agreement N. 793186 (RNASTIP).

Acknowledgments: A.D. and K.K.P. acknowledge funding from the European Union's Horizon 2020 research and innovation program under the Marie Skłodowska-Curie grant agreement N. 793186 (RNASTIP).

Conflicts of Interest: The authors declare no conflict of interest.

\section{References}

1. Fusaro, A.F.; Matthew, L.; Smith, N.A.; Curtin, S.J.; Dedic-Hagan, J.; Ellacott, G.A.; Watson, J.M.; Wang, M.B.; Brosnan, C.; Carroll, B.J.; et al. RNA interference-inducing hairpin RNAs in plants act through the viral defence pathway. EMBO Rep. 2006, 7, 1168-1175. [CrossRef] [PubMed]

2. Hamilton, A.J.; Baulcombe, D.C. A species of small antisense RNA in posttranscriptional gene silencing in plants. Science 1999, 286, 950-952. [CrossRef] [PubMed]

3. Chen, H.M.; Chen, L.T.; Patel, K.; Li, Y.H.; Baulcombe, D.C.; Wu, S.H. 22-Nucleotide RNAs trigger secondary siRNA biogenesis in plants. Proc. Natl. Acad. Sci. USA 2010, 107, 15269-15274. [CrossRef] [PubMed] 
4. Wu, H.; Li, B.; Iwakawa, H.; Pan, Y.; Tang, X.; Ling-hu, Q.; Liu, Y.; Sheng, S.; Feng, L.; Zhang, H.; et al. Plant 22-nt siRNAs mediate translational repression and stress adaptation. Nature 2020. [CrossRef]

5. Chan, S.W.; Zilberman, D.; Xie, Z.; Johansen, L.K.; Carrington, J.C.; Jacobsen, S.E. RNA silencing genes control de novo DNA methylation. Science 2004, 303, 1336. [CrossRef]

6. Wassenegger, M.; Heimes, S.; Riedel, L.; Sanger, H.L. RNA-directed de novo methylation of genomic sequences in plants. Cell 1994, 76, 567-576. [CrossRef]

7. Gallego-Bartolomé, J. DNA methylation in plants: Mechanisms and tools for targeted manipulation. New Phytol. 2020. [CrossRef]

8. Singh, J.; Pikaard, C.S. Reconstitution of siRNA Biogenesis In Vitro: Novel Reaction Mechanisms and RNA Channeling in the RNA-Directed DNA Methylation Pathway. Cold Spring Harb. Symp. Quant Biol. 2020. [CrossRef]

9. Cao, X.; Jacobsen, S.E. Role of the arabidopsis DRM methyltransferases in de novo DNA methylation and gene silencing. Curr. Biol. 2002, 12, 1138-1144. [CrossRef]

10. Liu, Z.; Shao, C.; Zhang, C.; Zhou, J.; Zhang, S.; Li, L.; Chen, S.; Huang, H.; Cai, T.; XJ, H. The SET Domain Proteins SUVH2 and SUVH9 Are Required for Pol V Occupancy at RNA-Directed DNA Methylation Loci. PLoS Genet. 2014. [CrossRef]

11. Yang, D.L.; Zhang, G.; Tang, K.; Li, J.; Yang, L.; Huang, H.; Zhang, H.; Zhu, J.K. Dicer-independent RNA-directed DNA methylation in Arabidopsis. Cell Res. 2016, 26, 66-82. [CrossRef] [PubMed]

12. Henderson, I.R.; Zhang, X.; Lu, C.; Johnson, L.; Meyers, B.C.; Green, P.J.; Jacobsen, S.E. Dissecting Arabidopsis thaliana DICER function in small RNA processing, gene silencing and DNA methylation patterning. Nat. Genet. 2006, 38, 721-725. [CrossRef] [PubMed]

13. Zilberman, D.; Cao, X.; Johansen, L.K.; Xie, Z.; Carrington, J.C.; Jacobsen, S.E. Role of Arabidopsis ARGONAUTE4 in RNA-directed DNA methylation triggered by inverted repeats. Curr. Biol. 2004, 14, 1214-1220. [CrossRef] [PubMed]

14. Dalakouras, A.; Dadami, E.; Wassenegger, M.; Krczal, G.; Wassenegger, M. RNA-directed DNA methylation efficiency depends on trigger and target sequence identity. Plant J. 2016, 87, 202-214. [CrossRef]

15. Dalakouras, A.; Wassenegger, M. Revisiting RNA-directed DNA methylation. RNA Biol. 2013, 10, 453-455. [CrossRef]

16. Otagaki, S.; Kawai, M.; Masuta, C.; Kanazawa, A. Size and positional effects of promoter RNA segments on virus-induced RNA-directed DNA methylation and transcriptional gene silencing. Epigenetics 2011, 6, 681-691. [CrossRef]

17. Li, Y.; Syed, J.; Sugiyama, H. RNA-DNA Triplex Formation by Long Noncoding RNAs. Cell Chem. Biol. 2016, 23, 1325-1333. [CrossRef]

18. Zhai, J.; Bischof, S.; Wang, H.; Feng, S.; Lee, T.F.; Teng, C.; Chen, X.; Park, S.Y.; Liu, L.; Gallego-Bartolome, J.; et al. A One Precursor One siRNA Model for Pol IV-Dependent siRNA Biogenesis. Cell 2015, 163, 445-455. [CrossRef]

19. Wierzbicki, A.T.; Cocklin, R.; Mayampurath, A.; Lister, R.; Rowley, M.J.; Gregory, B.D.; Ecker, J.R.; Tang, H.; Pikaard, C.S. Spatial and functional relationships among Pol V-associated loci, Pol IV-dependent siRNAs, and cytosine methylation in the Arabidopsis epigenome. Genes Dev. 2012, 26, 1825-1836. [CrossRef]

20. Wierzbicki, A.T.; Ream, T.S.; Haag, J.R.; Pikaard, C.S. RNA polymerase V transcription guides ARGONAUTE4 to chromatin. Nat. Genet. 2009, 41, 630-634. [CrossRef]

21. Matzke, M.A.; Mosher, R.A. RNA-directed DNA methylation: An epigenetic pathway of increasing complexity. Nat. Rev. Genet. 2014, 15, 394-408. [CrossRef] [PubMed]

22. Pelissier, T.; Thalmeir, S.; Kempe, D.; Sanger, H.L.; Wassenegger, M. Heavy de novo methylation at symmetrical and non-symmetrical sites is a hallmark of RNA-directed DNA methylation. Nucleic Acids Res. 1999, 27, 1625-1634. [CrossRef] [PubMed]

23. Pelissier, T.; Wassenegger, M. A DNA target of $30 \mathrm{bp}$ is sufficient for RNA-directed DNA methylation. RNA 2000, 6, 55-65. [CrossRef] [PubMed]

24. Aufsatz, W.; Mette, M.F.; Matzke, A.J.; Matzke, M. The role of MET1 in RNA-directed de novo and maintenance methylation of CG dinucleotides. Plant Mol. Biol. 2004, 54, 793-804. [CrossRef]

25. Lindroth, A.M.; Cao, X.; Jackson, J.P.; Zilberman, D.; McCallum, C.M.; Henikoff, S.; Jacobsen, S.E. Requirement of CHROMOMETHYLASE3 for maintenance of CpXpG methylation. Science 2001, 292, 2077-2080. [CrossRef] 
26. Law, J.A.; Jacobsen, S.E. Establishing, maintaining and modifying DNA methylation patterns in plants and animals. Nat. Rev. Genet. 2010, 11, 204-220. [CrossRef]

27. Baulcombe, D.C. VIGS, HIGS and FIGS: Small RNA silencing in the interactions of viruses or filamentous organisms with their plant hosts. Curr. Opin. Plant Biol. 2015, 26, 141-146. [CrossRef]

28. Eamens, A.; Wang, M.B.; Smith, N.A.; Waterhouse, P.M. RNA silencing in plants: Yesterday, today, and tomorrow. Plant Physiol. 2008, 147, 456-468. [CrossRef]

29. Koch, A.; Kogel, K.H. New wind in the sails: Improving the agronomic value of crop plants through RNAi-mediated gene silencing. Plant Biotechnol. J. 2014, 12, 821-831. [CrossRef]

30. Rosa, C.; Kuo, Y.W.; Wuriyanghan, H.; Falk, B.W. RNA Interference Mechanisms and Applications in Plant Pathology. Annu Rev. Pathol. Phytopathol. 2018, 56, 581-610. [CrossRef]

31. Dalakouras, A.; Wassenegger, M.; Dadami, E.; Ganopoulos, I.; Pappas, M.; Papadopoulou, K.K. Genetically Modified Organism-Free RNA Interference: Exogenous Application of RNA Molecules in Plants. Plant Physiol. 2020, 182, 38-50. [CrossRef] [PubMed]

32. Dubrovina, A.S.; Kiselev, K.V. Exogenous RNAs for Gene Regulation and Plant Resistance. Int. J. Mol. Sci. 2019, 20, 2282. [CrossRef] [PubMed]

33. Fletcher, S.J.; Reeves, P.T.; Hoang, B.T.; Mitter, N. A Perspective on RNAi-Based Biopesticides. Front. Plant Sci. 2020, 11. [CrossRef] [PubMed]

34. Joga, M.R.; Zotti, M.J.; Smagghe, G.; Christiaens, O. RNAi Efficiency, Systemic Properties, and Novel Delivery Methods for Pest Insect Control: What We Know So Far. Front. Physiol. 2016, 7, 553. [CrossRef]

35. Zotti, M.; Dos Santos, E.A.; Cagliari, D.; Christiaens, O.; Taning, C.N.T.; Smagghe, G. RNA interference technology in crop protection against arthropod pests, pathogens and nematodes. Pest Manag. Sci. 2018, 74, 1239-1250. [CrossRef] [PubMed]

36. Dalakouras, A.; Jarausch, W.; Buchholz, G.; Bassler, A.; Braun, M.; Manthey, T.; Krczal, G.; Wassenegger, M. Delivery of hairpin RNAs and small RNAs into woody and herbaceous plants by trunk injection and petiole absorption. Front. Plant Sci. 2018, 9, 1253. [CrossRef]

37. Dalakouras, A.; Wassenegger, M.; McMillan, J.N.; Cardoza, V.; Maegele, I.; Dadami, E.; Runne, M.; Krczal, G.; Wassenegger, M. Induction of Silencing in Plants by High-Pressure Spraying of In vitro-Synthesized Small RNAs. Front. Plant Sci. 2016, 7, 1327. [CrossRef]

38. Dubrovina, A.S.; Aleynova, O.A.; Kalachev, A.V.; Suprun, A.R.; Ogneva, Z.V.; Kiselev, K.V. Induction of Transgene Suppression in Plants via External Application of Synthetic dsRNA. Int. J. Mol. Sci. 2019, 20, 1585. [CrossRef]

39. Dubrovina, A.S.; Aleynova, O.A.; Suprun, A.R.; Ogneva, Z.V.; Kiselev, K.V. Transgene suppression in plants by foliar application of in vitro-synthesized small interfering RNAs. Appl. MicroBiol. Biotechnol. 2020. [CrossRef]

40. Mitter, N.; Worrall, E.A.; Robinson, K.E.; Li, P.; Jain, R.G.; Taochy, C.; Fletcher, S.J.; Carroll, B.J.; Lu, G.Q.; $\mathrm{Xu}$, Z.P. Clay nanosheets for topical delivery of RNAi for sustained protection against plant viruses. Nat. Plants 2017, 3, 16207. [CrossRef]

41. Niehl, A.; Soininen, M.; Poranen, M.M.; Heinlein, M. Synthetic biology approach for plant protection using dsRNA. Plant Biotechnol. J. 2018. [CrossRef] [PubMed]

42. Tenllado, F.; Diaz-Ruiz, J.R. Double-stranded RNA-mediated interference with plant virus infection. J. Virol. 2001, 75, 12288-12297. [CrossRef] [PubMed]

43. Tenllado, F.; Martinez-Garcia, B.; Vargas, M.; Diaz-Ruiz, J.R. Crude extracts of bacterially expressed dsRNA can be used to protect plants against virus infections. BMC Biotechnol. 2003, 3, 3. [CrossRef] [PubMed]

44. Yin, G.; Sun, Z.; Liu, N.; Zhang, L.; Song, Y.; Zhu, C.; Wen, F. Production of double-stranded RNA for interference with TMV infection utilizing a bacterial prokaryotic expression system. Appl. MicroBiol. Biotechnol. 2009, 84, 323-333. [CrossRef]

45. Koch, A.; Biedenkopf, D.; Furch, A.; Weber, L.; Rossbach, O.; Abdellatef, E.; Linicus, L.; Johannsmeier, J.; Jelonek, L.; Goesmann, A.; et al. An RNAi-Based Control of Fusarium graminearum Infections Through Spraying of Long dsRNAs Involves a Plant Passage and Is Controlled by the Fungal Silencing Machinery. PLoS Pathog. 2016, 12, e1005901. [CrossRef]

46. McLoughlin, A.G.; Wytinck, N.; Walker, P.L.; Girard, I.J.; Rashid, K.Y.; de Kievit, T.; Fernando, W.G.D.; Whyard, S.; Belmonte, M.F. Identification and application of exogenous dsRNA confers plant protection against Sclerotinia sclerotiorum and Botrytis cinerea. Sci. Rep. 2018, 8, 7320. [CrossRef] 
47. Nerva, L.; Sandrini, M.; Gambino, G.; Chittara, W. Double Stranded RNAs (dsRNAs) as a Sustainable Tool against Gray Mold (Botrytis cinerea) in Grapevine: Effectiveness of Different Application Methods in an Open-Air Environment. Biomolecules 2020, 10, 200. [CrossRef]

48. Song, X.S.; Gu, K.X.; Duan, X.X.; Xiao, X.M.; Hou, Y.P.; Duan, Y.B.; Wang, J.X.; Yu, N.; Zhou, M.G. Secondary amplification of siRNA machinery limits the application of spray-induced gene silencing. Mol. Plant Pathol. 2018. [CrossRef]

49. Wang, M.; Weiberg, A.; Lin, F.M.; Thomma, B.P.; Huang, H.D.; Jin, H. Bidirectional cross-kingdom RNAi and fungal uptake of external RNAs confer plant protection. Nat. Plants 2016, 2, 16151. [CrossRef]

50. Camargo, R.; Barbosa, G.; Possignolo, I.; Peres, L.; Lam, E.; Lima, J.; Figueira, A.; Marques-Souza, H. RNA interference as a gene silencing tool to control Tuta absoluta in tomato (Solanum lycopersicum). PeerJ 2016, 4, e2673. [CrossRef]

51. Gong, L.; Chen, Y.; Hu, Z.; Hu, M. Testing insecticidal activity of novel chemically synthesized siRNA against Plutella xylostella under laboratory and field conditions. PLoS ONE 2013, 8, e62990. [CrossRef] [PubMed]

52. Hunter, W.; Glick, E.; Paldi, N.; Bextine, B. Advances in RNA interference: dsRNA Treatment in Trees and Grapevines for Insect Pest Suppression. Southw. Entomol. 2012, 37, 85-87. [CrossRef]

53. Ivashuta, S.; Zhang, Y.; Wiggins, B.E.; Ramaseshadri, P.; Segers, G.C.; Johnson, S.; Meyer, S.E.; Kerstetter, R.A.; McNulty, B.C.; Bolognesi, R.; et al. Environmental RNAi in herbivorous insects. RNA 2015, 21, 840-850. [CrossRef] [PubMed]

54. Majidiani, S.; PourAbad, R.; Laudani, F.; Campolo, C.; Zappalà, L.; Rahmani, S.; Mohammadi, S.; Palmeri, P. RNAi in Tuta absoluta management: Effects of injection and root delivery of dsRNAs. J. Pest Sci. 2019. [CrossRef]

55. Taning, C.N.T.; Arpaia, S.; Christiaens, O.; Dietz-Pfeilstetter, A.; Jones, H.; Mezzetti, B.; Sabbadini, S.; Sorteberg, H.G.; Sweet, J.; Ventura, V.; et al. RNA-based biocontrol compounds: Current status and perspectives to reach the market. Pest Manag. Sci. 2020. [CrossRef]

56. Jones, L.; Hamilton, A.J.; Voinnet, O.; Thomas, C.L.; Maule, A.J.; Baulcombe, D.C. RNA-DNA interactions and DNA methylation in post-transcriptional gene silencing. Plant Cell 1999, 11, 2291-2301.

57. Dadami, E.; Dalakouras, A.; Zwiebel, M.; Krczal, G.; Wassenegger, M. An endogene-resembling transgene is resistant to DNA methylation and systemic silencing. RNA Biol. 2014, 11, 934-941. [CrossRef]

58. Dadami, E.; Moser, M.; Zwiebel, M.; Krczal, G.; Wassenegger, M.; Dalakouras, A. An endogene-resembling transgene delays the onset of silencing and limits siRNA accumulation. FEBS Lett. 2013, 587, 706-710. [CrossRef]

59. Kanazawa, A.; Inaba, J.; Kasai, M.; Shimura, H.; Masuta, C. RNA-mediated epigenetic modifications of an endogenous gene targeted by a viral vector: A potent gene silencing system to produce a plant that does not carry a transgene but has altered traits. Plant Signal Behav. 2011, 6, 1090-1093. [CrossRef]

60. Kanazawa, A.; Inaba, J.I.; Shimura, H.; Otagaki, S.; Tsukahara, S.; Matsuzawa, A.; Kim, B.M.; Goto, K.; Masuta, C. Virus-mediated efficient induction of epigenetic modifications of endogenous genes with phenotypic changes in plants. Plant J. 2011, 65, 156-168. [CrossRef]

61. Pontes, O.; Vitins, A.; Ream, T.S.; Hong, E.; Pikaard, C.S.; Costa-Nunes, P. Intersection of small RNA pathways in Arabidopsis thaliana sub-nuclear domains. PLoS ONE 2013, 8, e65652. [CrossRef] [PubMed]

62. Ruiz, M.T.; Voinnet, O.; Baulcombe, D.C. Initiation and maintenance of virus-induced gene silencing. Plant Cell 1998, 10, 937-946. [CrossRef] [PubMed]

63. Jiang, L.; Ding, L.; He, B.; Shen, J.; Xu, Z.; Yin, M.; Zhang, X. Systemic gene silencing in plants triggered by fluorescent nanoparticle-delivered double-stranded RNA. Nanoscale 2014, 6, 9965-9969. [CrossRef] [PubMed]

64. Lau, S.E.; Schwarzacher, T.; Othman, R.Y.; Harikrishna, J.A. dsRNA silencing of an R2R3-MYB transcription factor affects flower cell shape in a Dendrobium hybrid. BMC Plant Biol. 2015, 15, 194. [CrossRef] [PubMed]

65. Numata, K.; Ohtani, M.; Yoshizumi, T.; Demura, T.; Kodama, Y. Local gene silencing in plants via synthetic dsRNA and carrier peptide. Plant Biotechnol. J. 2014, 12, 1027-1034. [CrossRef]

66. Sammons, R.D.; Ivashuta, S.; Liu, H.; Wang, D.; Feng, P.; Kouranov, A.; Andersen, S. Polynucleotide Molecules for Gene Regulation in Plants. International Patent WO/2011/112570, 15 September 2011.

67. Bewick, A.J.; Ji, L.; Niederhuth, C.E.; Willing, E.M.; Hofmeister, B.T.; Shi, X.; Wang, L.; Lu, Z.; Rohr, N.A.; Hartwig, B.; et al. On the origin and evolutionary consequences of gene body DNA methylation. Proc. Natl. Acad. Sci. USA 2016, 113, 9111-9116. [CrossRef] 
68. Bewick, A.J.; Schmitz, R.J. Gene body DNA methylation in plants. Curr. Opin. Plant Biol. 2017, 36, $103-110$. [CrossRef]

69. Aufsatz, W.; Mette, M.F.; van der Winden, J.; Matzke, M.; Matzke, A.J. HDA6, a putative histone deacetylase needed to enhance DNA methylation induced by double-stranded RNA. EMBO J. 2002, 21, 6832-6841. [CrossRef]

70. Johnson, L.; Cao, X.; Jacobsen, S. Interplay between two epigenetic marks. DNA methylation and histone H3 lysine 9 methylation. Curr. Biol. 2002, 12, 1360-1367. [CrossRef]

71. Johnson, L.M.; Bostick, M.; Zhang, X.; Kraft, E.; Henderson, I.; Callis, J.; Jacobsen, S.E. The SRA methyl-cytosine-binding domain links DNA and histone methylation. Curr. Biol. 2007, 17, 379-384. [CrossRef]

72. Mette, M.F.; Aufsatz, W.; van der Winden, J.; Matzke, M.A.; Matzke, A.J. Transcriptional silencing and promoter methylation triggered by double-stranded RNA. EMBO J. 2000, 19, 5194-5201. [CrossRef] [PubMed]

73. Mette, M.F.; van der Winden, J.; Matzke, M.A.; Matzke, A.J. Production of aberrant promoter transcripts contributes to methylation and silencing of unlinked homologous promoters in trans. EMBO J. 1999, 18, 241-248. [CrossRef] [PubMed]

74. Wassenegger, M. The role of the RNAi machinery in heterochromatin formation. Cell 2005, 122, 13-16. [CrossRef] [PubMed]

75. Wassenegger, M.; Pelissier, T. A model for RNA-mediated gene silencing in higher plants. Plant Mol. Biol. 1998, 37, 349-362. [CrossRef]

76. Matzke, M.; Aufsatz, W.; Kanno, T.; Daxinger, L.; Papp, I.; Mette, M.F.; Matzke, A.J. Genetic analysis of RNA-mediated transcriptional gene silencing. Biochim. Biophys. Acta 2004, 1677, 129-141. [CrossRef]

77. Okano, Y.; Miki, D.; Shimamoto, K. Small interfering RNA (siRNA) targeting of endogenous promoters induces DNA methylation, but not necessarily gene silencing, in rice. Plant J. 2008, 53, 65-77. [CrossRef]

78. Voinnet, O. Use, tolerance and avoidance of amplified RNA silencing by plants. Trends Plant Sci. 2008, 13, 317-328. [CrossRef]

79. Manavella, P.A.; Koenig, D.; Weigel, D. Plant secondary siRNA production determined by microRNA-duplex structure. Proc. Natl. Acad. Sci. USA 2012, 109, 2461-2466. [CrossRef]

80. Xia, R.; Chen, C.; Pokhrel, S.; Ma, W.; Huang, K.; Patel, P.; Wang, F.; Xu, J.; Liu, Z.; Li, J.; et al. 24-nt reproductive phasiRNAs are broadly present in angiosperms. Nat. Commun. 2019, 10, 627. [CrossRef]

81. Uslu, V.V.; Wassenegger, M. Critical view on RNA silencing-mediated virus resistance using exogenously applied RNA. Curr. Opin. Virol. 2020, 42, 18-24. [CrossRef]

82. Papadopoulou, N.; Devos, Y.; Álvarez-Alfageme, F.; Lanzoni, A.; Waigmann, E. Risk Assessment Considerations for Genetically Modified RNAi Plants: EFSA's Activities and Perspective. Front. Plant Sci. 2020, 11. [CrossRef] [PubMed]

(C) 2020 by the authors. Licensee MDPI, Basel, Switzerland. This article is an open access article distributed under the terms and conditions of the Creative Commons Attribution (CC BY) license (http://creativecommons.org/licenses/by/4.0/). 